\title{
Food Supply Chain Disruptions and Resilience Under the Stress of COVID-19: Evidence from Nepal
}

\section{Saugat Khanal ${ }^{*}$, Padam Bahadur Poudel ${ }^{2}$, Jeevan Lamichhane ${ }^{3}$ and Alagathurai Ajanthan ${ }^{4}$}

${ }^{1}$ Faculty of Agriculture, Agriculture and Forestry University, Rampur, Chitwan, Nepal

${ }^{2}$ Paklihawa Campus, Institute of Agriculture and Animal Science, Paklihawa,

Rupandehi, Nepal

${ }^{3}$ Regional Agricultural Research Station, NARC, Khajura, Banke, Nepal

${ }^{4}$ Lecturer, Department of Accounting, University of Jaffna, Jaffna, Sri Lanka

*Corresponding Author: Saugat Khanal, Faculty of Agriculture, Agriculture and

Forestry University, Rampur, Chitwan, Nepal.
Received: June 20, 2020

Published: July 01, 2020

(C) All rights are reserved by Saugat

Khanal., et al.

\section{Abstract}

The food supply chain is a complex web with a number of stakeholders. Though the stocks of cereal at present are at satisfactory level, its stock in future is going to be depleted resulting from the disruptions in the food supply chain. Supply of agric-inputs has been severely affected. Developing countries and low income countries are most vulnerable to the impact of disruptions in the supply chain. Secondary sources of information are used for studying the food supply disruptions and resilience. Supply chain resilience has drained the curiosity of local to multinational companies and policymakers in remodeling the chain. As per the alarming projections to leave the long-term negative consequences, the importance of food availability has further risen. Consumer's anticipation of future food crises has created panic and chaos in the food market; affecting the demand-supply chain. Transportation and public restrictions including transnational boundaries lockdown have created inconvenience to producers and distributors. With numerous noted obstacles from farm to firm, unemployment and poverty among low and middle class have been particularly hard hit. In this regard there is a need for behavioral change of the consumer, diversification of the supply chain and consumption of the local food.

Keywords: COVID-19; Food-System; Resilience; Supply Chain Disruptions

\section{Introduction}

As the world wrestles with the humanity and economic crisis, supply chains are encountering idiosyncratic challenges [1] globally. The COVID-19 continues to impact most of the international sectors; the food supply chain is being squeezed severely than before [2]. The natural production sector has not been disturbed yet, (though new cycle may face heavy crash) resulting surplus of perishable items in farm, but lack in smooth supply have forced producers to destroy tons edible food products. This sounds heartrending that the fresh produce is being dumped and plowed back into the dirt as the shutdown of agro-industry has scrambled the food supply chain [3]. Despite the relatively strong food sufficient system and cutting-edge technology, food service industry in developed nations are also facing noteworthy and enduring impacts.
With the increasing recovery of COVID-19 cases and reopening of the economy, retainment and resiliency of the food supply chain has gained considerable attention. Supply availability in global supply chains has been terribly diminished and malfunctioned with the abruptly changing demand [4]. Sustaining the livelihood under lockdown conditions, almost half of the world's population has felt a drastic effect on the consumption patterns leading to the development of new consumers' patterns. Not only food and agricultural commodities, market imbalance is evident in medical, textiles, and pandemic accessories (e.g. masks, hand sanitizer, disinfection spray, some antibiotics, etc.). The whole world is moving forward with uncertainty. $40-60 \%$ of the world's population is estimated to be infected by coronavirus this year [5].

Citation: Saugat Khanal., et al. "Food Supply Chain Disruptions and Resilience Under the Stress of COVID-19: Evidence from Nepal". Acta Scientific Agriculture 4.7 (2020): 158-166. 
Low- and middle-income nations were already facing tough times maintaining their supply side (food production, imports, aid and stock exchanges) of food security, while global pandemic has brought it to further limelight. The economic repercussion from COVID-19 seems to be profound to date; at least $\$ 20$ trillion in a few weeks and it is estimated to exceed the 2008-2009 Great Recession in the near future [6]. Supermarket shelves remain closed for now. But the incessant pandemic crisis could expeditiously bring outstanding changes on the food supply chains. FAO $[7,8]$ says that empty shelves of supermarkets, logistic hurdles and slowdowns in shipping are signs of supply chains breakages in the coming weeks. Just to put this in perspective, we are tackling disruptions in food supply systems. Though, to date, no losses have occurred that are irretrievable -the world is yet to face the great economic recession. As most part of the world goes into self-isolation and quarantine, this pandemic is highlighting the vulnerability in the supply chain model and here comes the challenge of redesigning the food supply chain. Typical and relevant design thinking is needed that enables industries to reshape their supply chains. Thus, supply systems are vulnerable and almost certain to face shock. In this regard, this paper aims to study supply chain disruptions and sort out the relevant solutions to keep the supply chain resilient during and post-COVID era. This study is based on the secondary sources of information. This paper is based on the review of different publications. Different sources like FAO, World Bank, IMF, and GoN have been reviewed. Personal communications with many experts have been performed.

\section{Supply chain shocks in COVID-19}

Both demand and supply shocks have shifted the curve of the supply chain throughout the world. There's also a loss due to economic harm to the laborers whose jobs or working hours are cut and the emerging challenge of food insecurity for millions. Still and all, there are signs of positive hope, like the success of small grocers in maintaining the supply panels with the local sources [9]. Supply chain disruptions are engendering havoc with everything from supplies of toilet paper to meat, couldn't even imagine how foods are being supplied [10]. It's been a kind rush to determine demand and supply; who needs what and who has what? The sudden global lockdown condition has contributed to a massive economic shock: demand shocks and supply shocks.

\section{Demand-side}

Restricting trade is not a solution. Scarcity is not an issue this time as the supply of food commodities is functioning well till today. Nevertheless, panic buying or hoarding behaviors by consumers has increased the demand shocks even more. During the initial outbreak of a pandemic, people didn't pay much more attention to buying more foods. Later, consumers overwhelm the system by purchasing extra more products as would usually be consumed in a period of time. Even though the price of food is high, there's still a large demand for food. The demand for food commodities has drastically increased, shifting the demand curve to the right. But, the demand curve of non-agricultural commodities shifted to the left due to a decrease in the demand for non-agricultural commodities. Both consumers and businesses have less cash in their bank accounts causing declines in sales of goods and services.

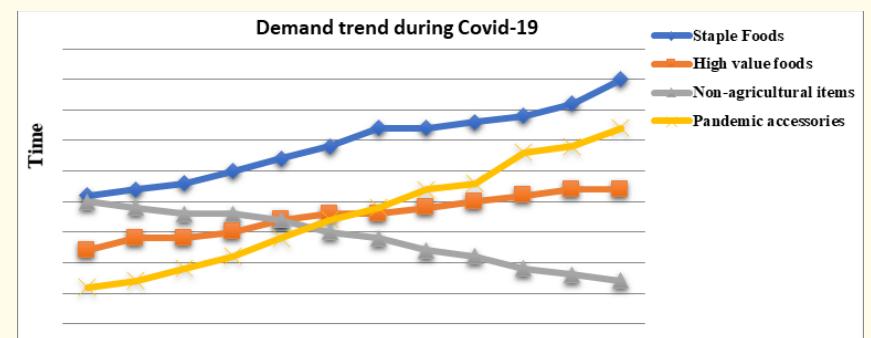

Figure 1: Demand trend of commodities during the pandemic. Source: [11].

The demand for staple foods (wheat, rice, corn, soybeans, etc.) has been rapidly increased during this pandemic in most of the countries. High-value foods (Fruits, vegetables, fishery, etc.), though are basics for living, are demanded high but not as many staple foods. The anticipation of a shortage of these food items has created panic in the public and people are buying haphazardly. The demand for non-agricultural food items has decreased due to the shortage of cash with the consumers. However, pandemic accessories; facial masks, hand sanitizers, disinfectants, etc. are consumed more by the people and its demand has increased irrespective of the price. We have already stated the stockpiling behaviors of the consumers in anticipation of movement restrictions and fear of dis- 
ruption to food supply systems. We notice a decrease in purchasing capacity due to decreased income, travel restriction, trade restriction, government tax policy, misleading concept of food as carrier of the virus.

Supply-side: What's genuinely unusual right now in the supply chain is the grocery stores seem to be heavy on the product; farmers are throwing away and dumping up the foodstuffs. Potential supply-side shocks include labor shortages, disruptions to transportation networks, and restrictions to borders with respect to the movement of goods. The suppliers even don't know where the demand lies and who is being deprived? A supply shock is anything that lessens the economy's potential to manufacture goods and services, at given prices [12]. Several economists have already anticipated the supply shocks caused by labor shortages [13-15]. Many businesses are not able to understand their supply chains including when and what goods will arrive. Labor shortages due to employee's illness, self-isolation, or movement restrictions have shocked the supply chain and impacted the essential supply of food from farms to industries and producers to consumers. Negative supply shocks have many effects- any increase in input cost expenses can cause the aggregate supply curve to shift to the left, which tends to raise prices and reduce output [16]. Shocks are unexpected events that cause changes in global economic growth, inflation, and unemployment. Throughout the pandemic, all countries are facing supply shocks to some degree. The fact is that the least developed countries are more vulnerable partly as they have a less diversified economy and circumscribe the range of production and export companies [17].

Disruptions in supply chain during this pandemic

Early in the outbreaks of COVID-19, one of the key anxieties was in relation to the constant supply of food. However, later, food shortages artificially produced by panic buying and stockpiling of essential basic elements, global food availability has generally been affected, but not adversely. A supply chain disruption is any unforeseen change which may be local or global that negatively impacts that chain [18]. It's fairly a short-term problem that a number of people are becoming unemployed right now- but what it means if people don't have as much cash as they normally would have to purchase goods and services. Movement restrictions have brought innumerable challenges in the production and marketing of the goods. Fall in consumer's income can be a long-run problem. The demand for income-elastic products has declined- because of which consumers substitute away from expensive foods. This ultimately affects the retailer's purchasing behaviors of food from suppliers. The demand for the restaurant's meals has turmoil due to social distancing. They have no consumers to have their meals. To maintain some income and sustain their business, they are shifting the way they sell their product. There is no extra food because it's expensive to store things for a long time. The threat of disruption is higher which is going to hit the worse than ever. Global exports of manufacturing inputs are estimated to be reduced by at least $\$ 228$ billion during the pandemic due to supply chain disruptions [19].

We see three levels of supply chain disruptions during this pandemic- local disruption in the global supply chain, large scale disruptions due to lock-down on all levels, and the broad range of local and global supply chain disturbances [20].

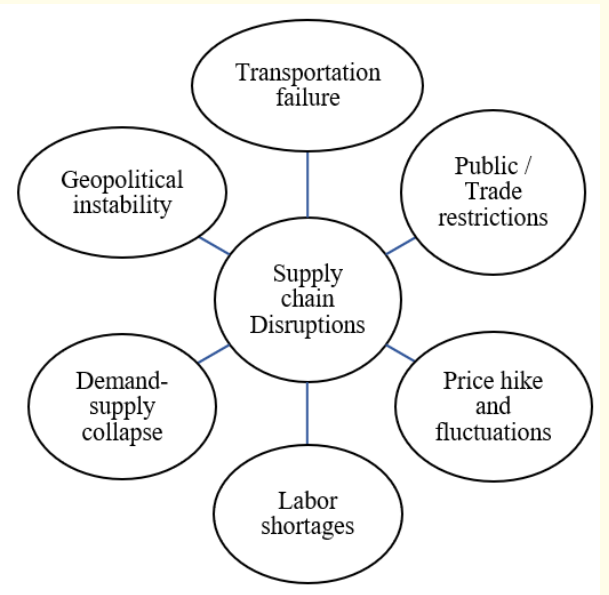

Figure 2: Causes of supply chain disruptions during the pandemic.

The restriction in transportation and public movements has evidently curbed the trade and supply of the essential goods, particularly with respect to long haul trucking. From eggs to yeasts; shoppers have been experiencing empty grocery store shelves and many have changed their shopping patterns, breaking the chain [21]. The price hiking and price fluctuations in the demanded food items have ensued demand-supply collapse. Production and marketing 
problems due to labor shortages are what we all know. Unemployment is devouring the economy of every country. Public fear is a long-term human impact while the actual risks are invisible.

\section{Supply chain resilience}

Resilience after disruptions is what we want and immediate need of every company. The economic chief of FAO has stated that there is no paucity of food items around the world but rather the bottlenecks of access and logistics to reach consumers $[7,8]$. The resilience of the food supply chain is gaining attention by companies and policy makers. Several pieces of research and analysis have appeared in recent times that highlight the significance of this topic in the economic world. Keeping the health of the public in the center of prime importance, countries should meet the needs of most vulnerable people. There are two major problems today: Health crisis and Food crisis.

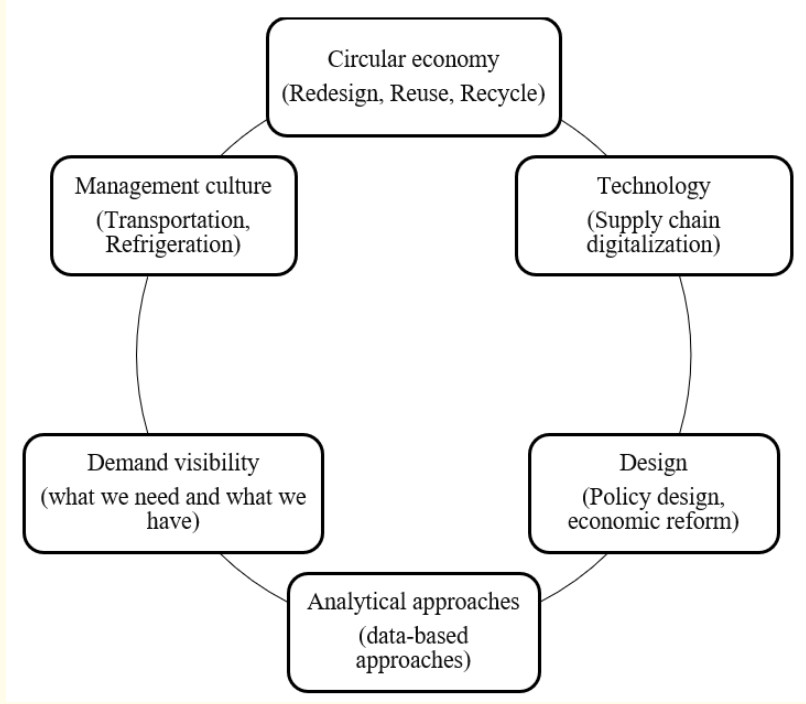

Figure 3: Steps of supply chain resilience.

Country must keep a balance between the need to keep production going and the need to protect the workers. Risk understanding is a vital starting point for management procedures- what are the risks, their likelihood, and how we can tackle them. There may be room for individuals and organizations to leverage the profits of the immediate community instead of global supply chains, endorsing principles of the redesign, reuse, and recycle (circular economy concept). Food supply chains in the near future may shift back to seasonal produce and local growth and supply. Reshaping the disrupted supply chain model using modern technological innovation seems to be possible for developed countries rather than developing ones. Almost half of the world's population is under self-quarantine; the supply of foods through workers is hard [22]. So, the supply is easier with the digital application; use of drones, delivery machines, etc. Blockchain permits food items to be actively traced throughout the supply chain. Protective means can be used during the delivery of goods. The majority of the consumers are having problems with payment. That's why the online system of payment, cash transfers mechanism, and mobile payments can be promoted. The old schemes, plans, and policies of economic development are worthless during the pandemic. Designing new strategies, plans, rules, and regulations can help somehow in supply chain resilience. Supply chain diversification can also be beneficial in remodeling. Expansion and improvement of emergency food assistance and social protection programs are the need of today for many countries. Vulnerable people staying at home-regulations should be protected from food scarcity. The data available about vulnerable people can be helpful to deliver food to the affected people with the help of food banks and community-based groups.

\section{Scenario of Nepal}

Looking out at the potential risks the COVID-19 could bring, the Government of Nepal (GoN) declared the school closures on $18^{\text {th }}$ March and the national lockdown on $24^{\text {th }}$ March, urging people to stay at home and shut down the businesses and the markets. Its impact has already started to lie in a number of sectors like tourism, trade and production linkages, supply, and health. The year 2020 should be the "Tourism Year" in Nepal. But what actually happened ruined everything- affecting the health and the economic sectors worst. Transportation restrictions became major bottlenecks in economic growth as it disrupts the supply chain of the commodities. No doubt, the lockdown measures may help the country win against the virus- but if the patterns of essential items supply and distribution continue to be disrupted, hundreds of thousands will lose their livelihood, and the whole nation could find itself drowning into deep food and economic crisis.

Import and export scenario: Nepal has long been choked between two economic giants; India and China. Reports reveal that 
more than $80 \%$ of the imports are from these two countries only. Nepal majorly relies on India, Bangladesh, China, and other foreign countries on agricultural inputs. It also imports bulky mass of the vegetables, food items, high-value foods, and other products. Since antiquity, Nepal has been importing a major quantity of agricultural commodities from India. However, the cross-border trade has been somehow difficult and risky due to the possibility of virus transmission. Though it is no full-stop in the trade between the countries, the pandemic has made it inconvenient in supply and distributions. Why are we just talking about cross-border trade? Even inside the country, the trade has collapsed unexpectedly. The break in export and import has drastically declined the economic growth rate of Nepal. Economic experts have already estimated a sharp fall of GDP growth rate to $2.3 \%$ in the fiscal year 2019/20, much lower than the $7.1 \%$ last fiscal and the government's preCovid-19 estimation of $8.5 \%$ [23].

For a country blessed with an ideal climate for a large variety of organic vegetables, Nepal should have been an exporter of fresh produce. However, in 2019, the country imported Rs 14.6 billion worth of vegetables from China and India [24]. Half of the vegetables marketed in the country used to be imported from India. It is reduced to almost a quarter of the vegetables imported from India during the period of lockdown. Agricultural commodities are inflowing to Nepal from India even during the trade restrictions. But it's not going to satisfy the needs for many days. The availability of the fertilizers, seeds, pesticides, and the needed inputs during this period is the topic of concern. We don't know if global fertilizer companies are going to manufacture and export at the time of crisis and severe shortages of manpower. Transportation services have been adjourned except for the supply of essential goods and services and industrial processing has also been largely on standstill. From the export-side, India as a large pie (65\%) and the United States (12\%) are the major markets for Nepali commodities [25]. Nepal exports tea, coffee, cardamom, ginger, apples, sugarcane, rice, fruits, etc. to different countries of the world. But, the pandemic, transport restrictions, and the public lockdown have shifted the export and import curve of the country to the left indicating negative sign. The inter-districts supply of food items, even being possible, isn't as easy as it was before the early outbreak of the virus. Due to the retard of transportation services, millions of tons of fresh vegetables are being rotten in the farm.
Phases of lockdown and effects in demand and supply

On $18^{\text {th }}$ March, the government proclaimed the hold of all classes and suspended all academic examinations including Secondary Education Examination (SEE). All government and private offices, industries, and companies except those providing essential services were shut down. Visa-on-travels were stopped with the closure of international and national airports. The government closed the land border entry points for the third-country nationals and declared two-week mandatory self- and home-quarantines for everyone visiting Nepal. The manufacturing industry is encountering a shortage of raw materials, most of which used to come from China and India. Remittances were anticipated to largely drop after Nepal suspended the issuance of worker's permit to Nepali for all countries. It has already been 75 days of lockdown and the pattern of restrictions has now changed to new. Within the days of lockdown, the public shows different behaviors and perspectives that affect the economy of the country ultimately. We divide the lockdown period and its effect in the economy and supply chain in three phases:

1. Phase 1 (First 30 days of country lockdown): Soon the country declared lockdown throughout all the districts, panic buying of the food items, and essential accessories stuck in the mind of all the denizens. The suppliers then started to charge more picking the advantage of the expected future crisis. After the cross-border supply appears to be a risk, the demand for the foods even increases more which creates a rumor of future food scarcity in the public. The consumers started buying the products even paying high prices. No transportations were allowed to the district as there were strict securities in the inter-district border too. The demand for food items goes on increasing while the supply goes on decreasing. People started to save money for food and the demand for non-agricultural goods diminished. This impacted the supply chain of the country.

2. Phase $\mathbf{2}$ ( $\mathbf{3 0}$ - $\mathbf{5 5}$ days of lockdown): Continuous lockdown in the room for many days due to lockdown became ennui to the people and they started to walk outside in the name of morning/evening walk, buying goods, and other excuses. The government listed the zone of risk on the basis of color; green zone- no risk at all and people can reopen the business, red 
zone-highly risked zone, and yellow zone- partially risked and people can only reopen the essential services and offices. The supply is more successful as compared to phase 1 . The flow of goods and foods cover the diminished economy with goodness. The supply chain started to regain its original line.

3. Phase 3 (last 55 - 75 days of lockdown): A public scream to ease the lockdown has initiated to emerge, with daily wage laborers facing inconvenience finding food and business complaining of losses. The country, lying in the probable stage of food deficit and economic crisis, decided to elude the lockdown and reopen. Short-run vehicles were permitted to run, but with certain rules and regulations as per the government. Truck carrying goods were not restricted that strengthened the supply chain. The products were made accessible from farms to consumers in an easier way. Slowly and gradually, the demand-supply curve is shifting in the right way. Finally, the government either eases lockdown or completely lifts the lockdown soon.

\section{Triggers of global food supply chain resilience}

The global level transmission happened faster than anyone could imagine. Starting as the health debacle, it turns into an economic catastrophe. The disruptions in the supply chain hurt producers and consumers and even create panic among the public. Well, yet the disruptions aren't worse, Resilience can be built into a system in advance of a disruption (Re-engineering). Food supply can't be secerned from how it is distributed- the logistics and supply of any product will always crumble from the 'last mile'. Since the end of World War-II, it is the first time that both supply and demand curves have been entirely warped synchronously [26]. The COVID-19 outbreak has battered numerous industries, but not all to the same level of ravage. Industries like auto, transport, consumer goods, electronics, and retail have been immensely tormented. The uttermost approach to deliver the needed supplies to a worsthit area is by re-shaping pre-pandemic supply chains.

Governmental role: Goods carrier and supply shouldn't be cramped like public restrictions. The country must keep the food supply flowing. In the long run, the government needs to invest in improving the emergency outbreak preparedness across the food supply chains. Smallholder farmers should be encouraged to enhance their productivity and market the food they produce on the farm; also through e-commerce channels. The policy for waiving farmer's loan or deferment of payment deadline can help to keep the farmers motivated in the continuous production of foods even during the time of lockdown. It should focus on trade and tax policies to keep the global trade open. We require pertinent infrastructure, staffing and delivery capacity. The government must collaborate with private organizations to preclude disruptions to food supply chains. It also should focus on rapid relevant technological advances. All countries are staring down the barrel of a funding dearth. Already many organizations have made cuts or disclosed. Keeping this point in view, countries need to save the budget for post-Covid economic reformation. Incentives to farmers and the daily workers, who used to rely on wages, can keep the production and supply chain working in the perfect line. The government can smoothen and strengthen the cross-border supply through twonation diplomatic talks rather than completely closing the border entry points.

Public level (Consumer's) role: We have no alternatives against the government's imposing the movement restrictions and business shutdown. The public, respecting the government's decision, should follow the rules and regulations and put themselves under self-isolation so that they can keep the society safe. WTO and FAO have already announced that there isn't going to be food scarcity very soon as these organizations are working with their best efforts in producing, supplying, and distributing the basic foods to the most vulnerable people of the least developed countries. To reshape the disrupted supply chains is partially in the hand of public people. They can help build supply chain resilience showing proper concern while buying the commodities. They shouldn't panic and involve stockpiling of the foods as it creates an imbalance in the market supply. The consumers can shift towards the consumption of locally produced foods- product diversification can help to enhance the supply chain resilience.

Stakeholder's role: From their side, they should develop relevant strategies to build links that result in impressive communication, coordination, and co-operation among overwhelmed parties. They may identify factors affecting resilience and analyze potential mitigating measures. They also can characterize spatial and temporal considerations like urgent planning and response timeframes. First and foremost, the prime work of stakeholders is to determine the potential stumbling blocks and gaps such as political boundaries, 
jurisdictions, ownership, competition, and connectivity in the market, and social and environmental curbs. The stakeholders must be able to corroborate the urgent demand of the public and how the supply is going. The thing they should know is "what is demanded" and "what and how are supplied?" Emergency managers should adopt this instruction to develop or refine logistics plans or annexes, following the six-step planning process described in the figure 4 below.

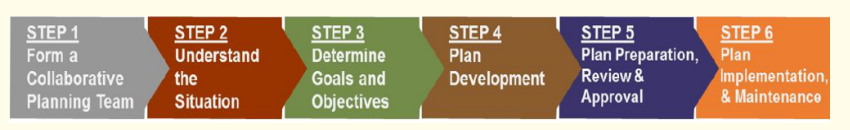

Figure 4: Stakeholder's role in building resilient supply chain. Source: [27].

They should collaborate with and among the partners of the supply chain to make supply chains of the most critical goods and services more resilient. Also, awareness programs of supply chains and economic vulnerabilities can be used in making recovery planning.

Farmer's role: There shouldn't be a much worse condition so that farmers stop producing the foods due to lack of capital, market accessibility, and the paucity of the needed inputs and infrastructures. Though the farmers are not getting the proper markets to sell their products, they can still sell their products in the local areas- localizing the produced produce. There is not only the option to dig the foods in the dirt, but they can maintain the same level of earnings by selling them in their own locality and developing post-harvest technology. If the foodstuffs are to be transported to the distant market, all the farmers of the community should gather their produce in a common collection center from where that can be distributed to different markets making effective policies. The collection center should have a high capacity. They can improve the storage facilities to preserve the foods from post-harvest losses. The producers can also develop the home-delivery mechanism so that the supply of essential foods doesn't cut off. Moreover farmers can also adopt product diversification strategies if they can't sell their product.
Post-Covid-19 possible changes in food supply chain

While it is very arduous to anticipate exactly how life will look once normality has resumed, it is unavoidable that neither business nor society as a whole will return to absolutely how it was before the pandemic hit.

Changing consuming behaviors: The consequential increase in home delivery and Click and Collect in all facets will influence more heavily in consumer buying behavior than it was hitherto, due to many shoppers having become even more customary to purchasing goods in this way. This will have a domino effect on markets, as, if these paradigms do truly persist, they will, in turn, affect both businesses' capacity a way to satisfy changing consumer's behavior, and their cost to serve.

Supply chain diversification and independence: International companies will widen the range of manufacturing, and their sources of supply as well, not bounding just in international trade and, if possible, form a regionalized network to serve demand. Having experienced a big lesson from Covid-19, countries will give priority to developing 'domestic supply chain independence' to avert another plight of national emergency and economic and health crises. Most investment experts comply that, although it doesn't ensure against the loss, source diversification is determining component of reaching sustainable financial goals while minimizing the risk of the supply chain disruptions [28]. The distorting of the supply chain footprint dynamic may accelerate as enterprises search for a different cost/resilience trade-off and look to localize production and sourcing.

Shift towards the local foods: New product lines may develop, with the chance of a reduction and shift in consumer choice for products. Prior to the pandemic, the consumers have had a wide range of choices of the products when they visit supermarkets. However, it will not be the same after the pandemic ends. As most of the consumers are habitual to the consumption of the local foods, they will shift to it and try to consume more fresh and organic produce rather than packaged dry foods. It will consequently shift the consumer's demand pattern. Though organic foods are quite expensive than conventional foods, people always prefer to 
have local organic foods knowing the fact about their freshness and healthiness [29]. The pandemic is increasing consumer awareness of the relationship between health and organic foods. Local food has always gained much popularity - and during this crisis, the consumption has been even higher [30-33].

\section{Conclusion}

COVID-19 has been the black swan event that eventually forces many national and international companies, and industries, to rethink and reshape their global supply chain model. Manufacturing industries have been battered in two waves: global supply chain disruptions and internal operational regional disruptions. The advanced countries like the USA, China, Britain, Russia, Italy, France, etc. are adversely affected and are more prone to trade imbalance. Food supply is an essential and emergency need for every country today. However, the effective channel for food supply has yet not been designed. Everywhere there is chaos; public anticipation of the future's food crisis has created panic in the society due to which the demand curve has been shifted and distorted than what it should be. Farmers aren't getting the market to sell their product and they are throwing away the foodstuffs on the roadside. Country lockdown and industries shutdown has affected the production and distribution of the essential food items. Also, marketing hasn't been convenient. Poverty and Unemployment are timely rising and the country is in the state of declaring a health and economic crisis soon. Keeping this point in view and to be safe from the expected crisis, the supply chain should be reshaping with the potential efforts of experts in the related fields. The government should make an immediate council of supply chain management and work for the risk management that this pandemic could bring soon. Efforts should be made from farmer's level to government and international level. The demand of the consumers and the supply by suppliers during the period of lockdown should be well understood and based on these effective plans and policies should be made. The faster we react to the crises, the sooner we can trounce any future disruptions or outbreaks. Thus, the concern for remodeling the supply chain should be focused on.

\section{Acknowledgement}

We are sincerely thankful to Mr. Dikshit Poudel, MS student of agricultural and applied economics, University of Georgia, United States of America (USA) for his advice and encouragement throughout the manuscript preparation.

\section{Bibliography}

1. Seifert RW and Markoff R. "Digesting the shocks: how supply chains are adapting to the COVID-19 lockdowns". Lausanne, Switzerland: International Institute for Management Development (IMD) (2020).

2. Bhandari S. "Publicis Sapient". COVID-19: What's Next for Food Supply Chains? (2020).

3. World Bank. "Food Security and COVID-19" (2020).

4. Ivanov D and Dolgui A. "Viability of intertwined supply networks: extending the supply chain resilience angles towards survivability. A position paper motivated by COVID-19 outbreak". International Journal of Production Research 58.10 (2020): 2904-2915.

5. Jarsulic M. "The Spread of Coronavirus Threatens Supply Shocks at Home and Abroad". Center for American Progress (2020).

6. Djalante R., et al. "Building resilience against biological hazards and pandemics: COVID-19 and its implications for the Sendai Framework". Progress in Disaster Science 6 (2020): 1-7.

7. FAO. "Food and Agriculture Organizations". United Nations (2020).

8. FAO. "Tackling COVID-19's effect on food supply chains in Africa". Food and Agriculture Organizations of the United Nations (2020).

9. Anupindi R. "COVID-19 shocks food supply chain, spurs creativity and search for resiliency". Michigan News (2020).

10. Taherian S. "Covid Shortages: Supply Chains Must Become Less Efficient". Forbes (2020).

11. Suneja K. "Huge demand for food products in global markets due to COVID-19 outbreak". The Economic Times (2020).

12. Brinca P., et al. "Is the COVID-19 Pandemic a Supply or a Demand Shock?" Economic Research (2020): 31.

13. Dingel J and Neiman B. "How many jobs can be done at home?" Becker Friedman Institute White Paper (2020). 
14. Hicks MJ., et al. "Occupational Exposure to Social Distancing: A Preliminary Analysis using O*NET Data (2020).

15. Koren M and Pető R. "Business disruptions from social distancing”. General economics: arXiv (2003): 13983.

16. Ross E. "Why Do Supply Shocks Occur and Who Do They Affect?" Investopedia (2019).

17. Tutor 2u. "Demand and Supply-Side Economic Shocks". Economics (2020).

18. Meyer S. "Combatting Ecommerce Supply Chain Disruptions and Steps You Can Take to Minimize Impact". Big Commerce (2020).

19. Solleder 0 and Torres M. "The Great Shutdown: How COVID-19 disrupts supply chains (2020).

20. Wyman 0. COVID-19: Managing Supply-Chain Disruption (2020).

21. Christine R. "Can price hikes by businesses ever be justified?" BBC Worklife (2020).

22. Dahir LA. "Instead of Coronavirus, the Hunger Will Kill Us.' A Global Food Crisis Looms". The New York Times (2020).

23. Sapkota C. "Covid-19: Impact and response". The Kathmandu Post (2020).

24. Kumar R. "Nepal lockdown chance for self-sufficiency in veggies". Nepali Times (2020).

25. Bist JP. "To reduce the trade deficit, Nepal has to rely on agriculture". The Kathmandu (2019).

26. Easen N. "Why COVID-19 presents a supply chain opportunity" (2020).

27. Homeland S. Supply Chain Resilience Guide (2019).

28. Lioudis NK. "The Importance of Diversification". Investopedia (2019).

29. Khanal S. "Consumers' willingness, behaviors, and attitudes to pay a price premium for local organic foods in Nepal”. International Journal of Environment, Agriculture and Biotechnology (2020): 594-609.
30. Hoberg K and Alicke K. "5 Lessons for Supply Chains from the Financial Crisis”. Supply Chain (2014): 247.

31. Cordon C and Buatois E. "A post COVID-19 outlook: the future of the supply chain". Research and Knowledge (2020).

32. Ostdick N. 5 Primary Causes of Supply Chain Disruptions (2017).

33. Seric A., et al. "Managing COVID-19: How the pandemic disrupts global value chains". World Economic Forum (2020).

\section{Assets from publication with us}

- Prompt Acknowledgement after receiving the article

- Thorough Double blinded peer review

- Rapid Publication

- Issue of Publication Certificate

- High visibility of your Published work

Website: www.actascientific.com/

Submit Article: www.actascientific.com/submission.php

Email us: editor@actascientific.com

Contact us: +919182824667 